\title{
Food Security: Impact of European Settlement and Infrastructure on Columbia River Salmon Migration
}

\author{
Kenneth R. Olson ${ }^{*}{ }^{\circledR}$, Cory D. Suski² \\ ${ }^{1}$ College of Agricultural, Consumer, and Environmental Sciences, University of Illinois, Urbana, Illinois, USA \\ ${ }^{2}$ Department of Natural Resources, College of Agricultural, Consumer, and Environmental Sciences, University of Illinois, \\ Urbana, Illinois, USA \\ Email: ^krolson@illinois.edu
}

How to cite this paper: Olson, K.R. and Suski, C.D. (2021) Food Security: Impact of European Settlement and Infrastructure on Columbia River Salmon Migration. Open Journal of Soil Science, 11, 367-388. https://doi.org/10.4236/ojss.2021.117019

Received: June 8, 2021

Accepted: June 28, 2021

Published: July 1, 2021

Copyright $\odot 2021$ by author(s) and Scientific Research Publishing Inc. This work is licensed under the Creative Commons Attribution International License (CC BY 4.0).

http://creativecommons.org/licenses/by/4.0/

\begin{abstract}
The $2000 \mathrm{~km}$ Columbia River is the longest river in the Pacific Northwest region of North America. It starts in British Columbia, Canada and flows through the states of Oregon and Washington before discharging into Pacific Ocean near Cape Disappointment. The mouth of the Columbia River is a deep water harbor and $180 \mathrm{~km}$ of the river can be accessed by navigation. Based on flow volume, the river is the $4^{\text {th }}$ largest river in the United States. The headwaters and approximately $800 \mathrm{~km}$ of the Columbia River lie in Canada. Columbia Lake and the Columbia Wetlands are located in British Columbia and are the headwaters of the Columbia River. The lake has an elevation of $820 \mathrm{~m}$ above sea level and drains to the Pacific Ocean near Astoria, Oregon. The Ocean tides flow up river to Portland, Oregon. This paper highlights how the geological and landscape resources of the Columbia River and tributaries watershed contributed to the economic development of this historically rich region of North America. The Columbia River is one of the most biologically diverse freshwater systems in the United States. The Columbia River system with trails and cruise ships was designed to increase use of the Columbia River, to promote recreational tourism, and to create a generation of people who are willing to protect and provide environmental stewardship of the river basin resources.
\end{abstract}

\section{Keywords}

Bonneville Slide, Land of Flowing Milk and Honey, Lewis and Clark Expedition, Missoula Flood, Mount St. Helens, Oregon Trail, Willamette Valley 


\section{Introduction}

In the 1700 s, there was a strong interest in the discovery of a Northwest Passage that would permit navigation between the Pacific Ocean and the Atlantic Ocean or inland North America. Many European ships, including those under British and Spanish command, searched the northwest coast for a large river, such as the Columbia and Snake Rivers (Figure 1), that connected to either the Missouri River [1] [2] or to Hudson Bay [3]. The Columbia River was at the same latitude as the headwaters of the Missouri River. A 1798 British map showed a dotted line connecting the Missouri River with the Columbia River (the dotted line was through the Rocky Mountains). American explorers, Meriwether Lewis and William Clark (Figure 2) in 1805 and 1806, found no such passage between these rivers. David Thompson, a Canadian explorer for the Northwest Company, became the first European-American to travel the entire length of the Columbia River. After 1825, the Hudson's Bay Company controlled the Columbia River and American attempts to gain territorial control were fended off. The Hudson's Bay Company attempted to establish settlements north of the Columbia River and rekindled the issue of "joint occupation" which created a boundary dispute. In the 1840s Americans began to colonize the Oregon territory. They arrived via the Oregon Trail (Figure 3 and Figure 4). The Oregon Treaty of 1846 set the boundary between the United States and Canada at the $49^{\text {th }}$ parallel. The Columbia River became the western border of the U.S. territories of Washington and Oregon.

The Columbia River (Figure 5) and its tributaries have been vital to region's economy and culture for centuries [4]. The river system is home to many species of fish including salmon (Oncorhynchus gorbuscha; Oncrhynchus tshawytscha; Oncorhychus kisutch) and steelhead (Oncorhynchus mykiss), which provided

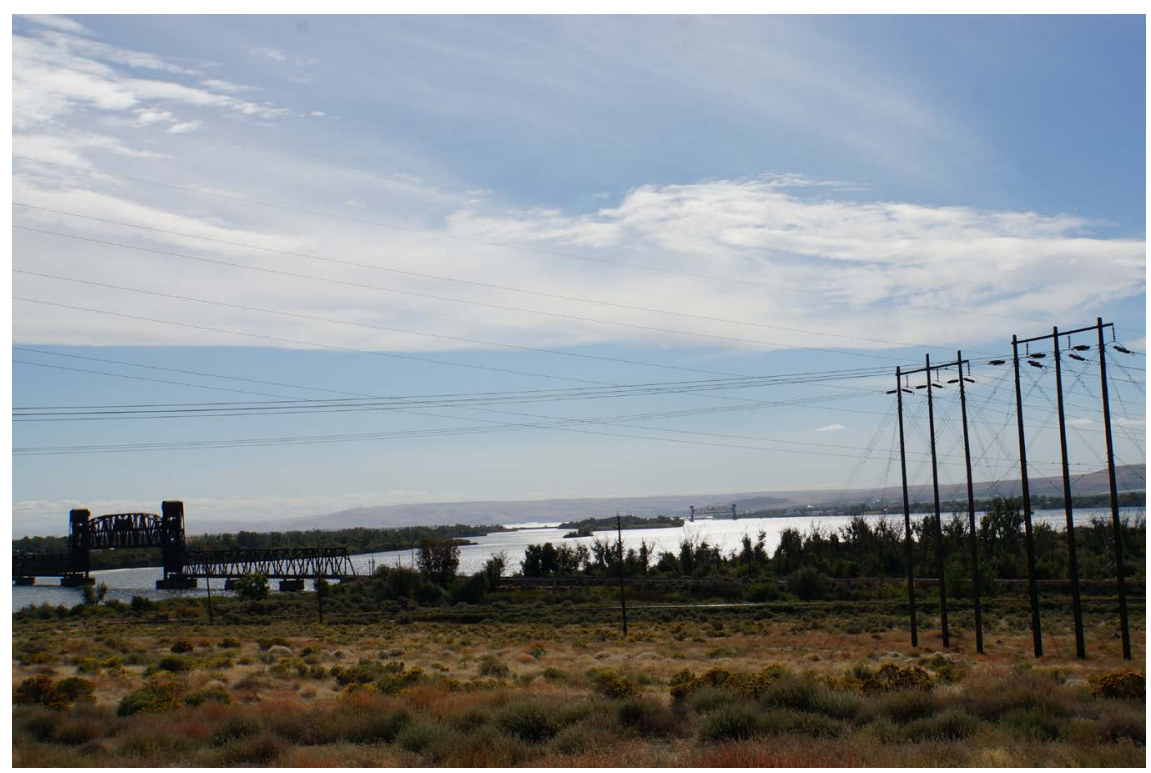

Figure 1. The confluence of the Columbia and Snake Rivers. Photograph by Lois Wright Morton. 


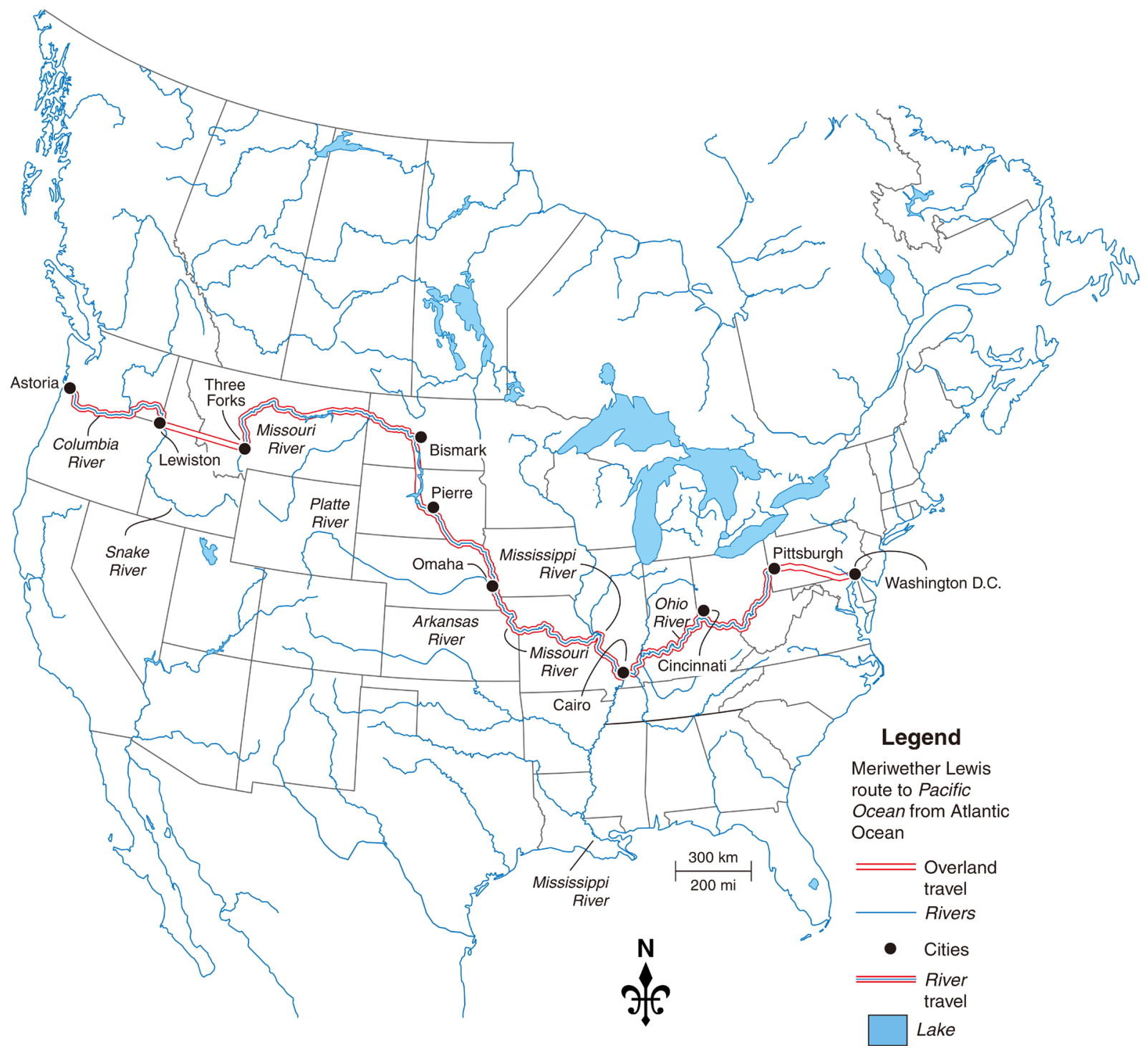

Figure 2. The 1803 to 1805 Meriwether Lewis route from the Atlantic Ocean to the Pacific Ocean. Map by Mic Greenberg.

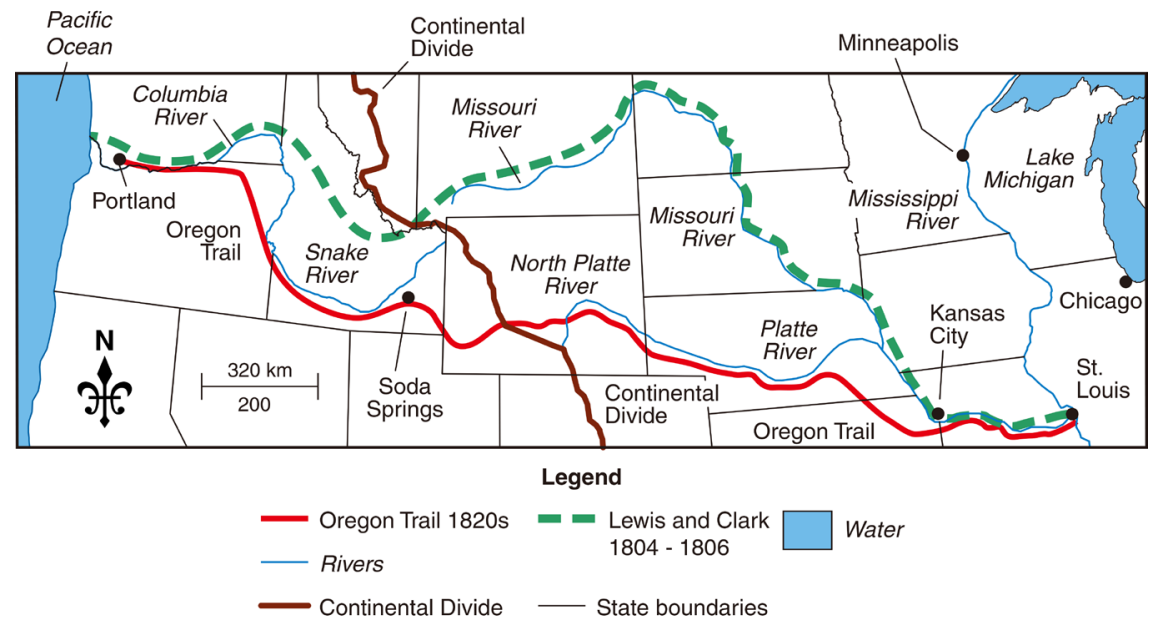

Figure 3. The Oregon Trail from St. Louis along the Missouri River, Platte River, North Platte River, overland to the Snake River and the Columbia River to the Cape Disappointment and the Pacific Ocean. Map by Mic Greenberg. 


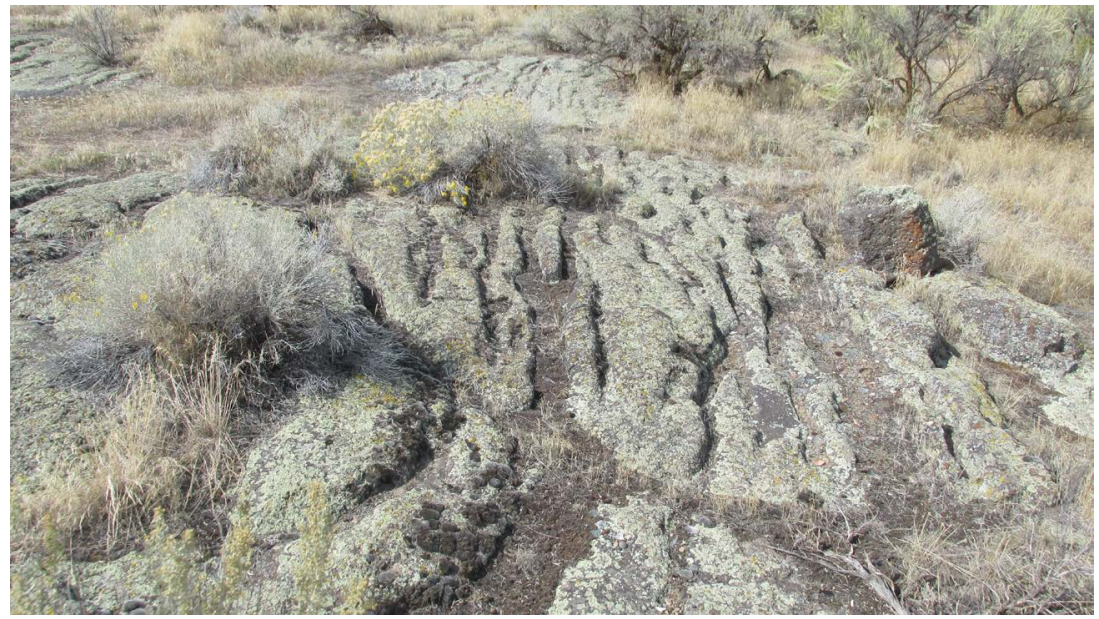

Figure 4. Wheel tracks on bedrock along the Oregon Trail in Idaho. The steel strips were attached to the wooden wheels cut into the stone and these cuts were weathered for over 200 years. Photograph by Lois Wright Morton.
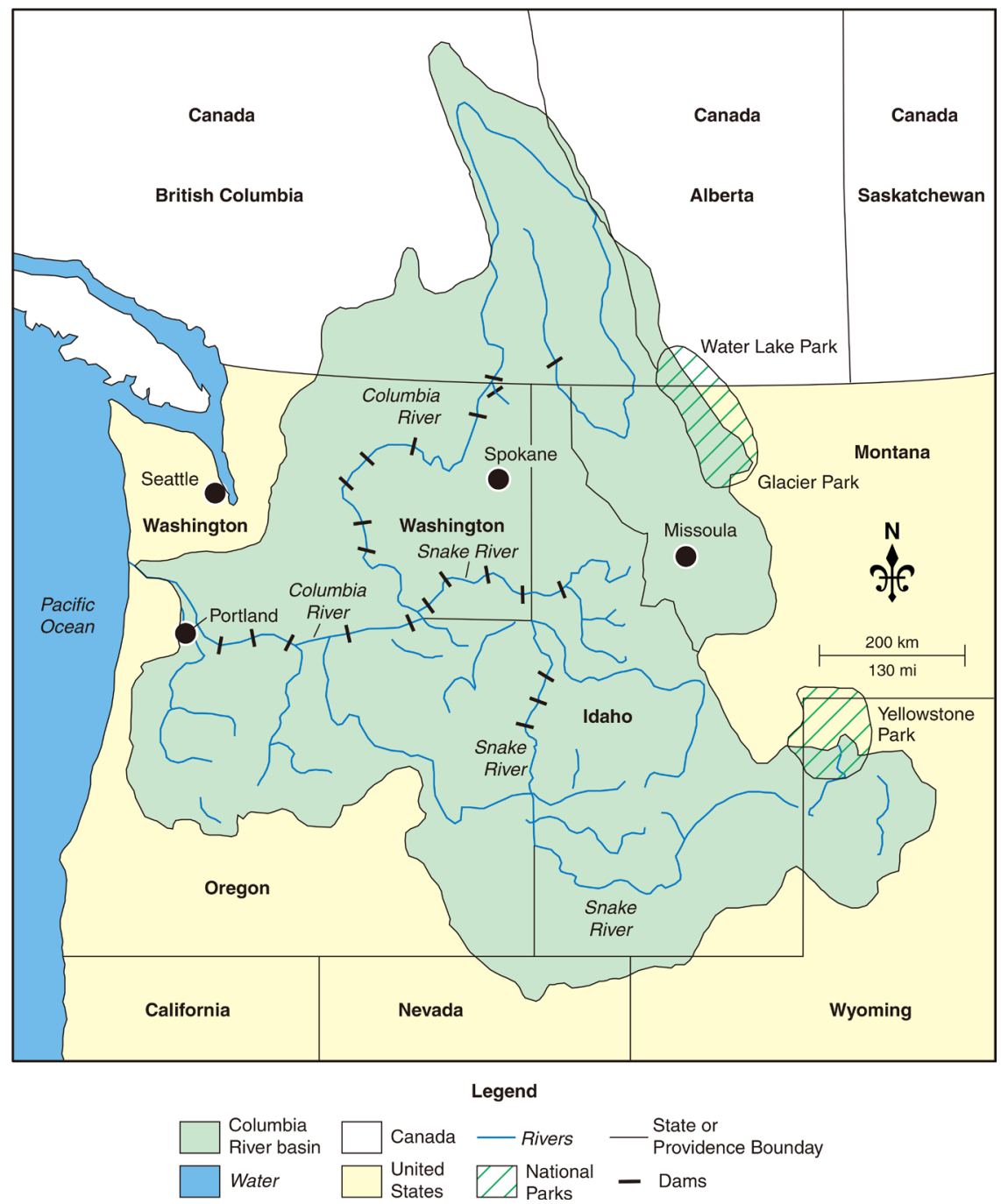

Figure 5. The Columbia River and Snake River basins located in northwestern United States and southwestern Canada. Map by Mic Greenberg. 
the primary food source for local Native Peoples. Later, the Columbia River was used as a transportation route by the fur trading companies. In the late 1700s, American and British explorers entered the river, passed through the Oregon Coast Range and into the agriculturally productive Willamette Valley, known by Oregon Trail travelers as the "Land of Flowing Milk and Honey". American settlers traveled overland on the Oregon Trail and into the Willamette Valley through the Columbia River Gorge. Steamships facilitated trade and linked communities. In the 1800s, railroads running along the rivers competed with the steamboats. Locks have been built along the lower Columbia and tributaries to aid navigation. Dredging was required to maintain navigation channels. Barge traffic was possible to Lewiston, Idaho, a distance of $740 \mathrm{~km}$ from the Pacific Ocean [5] with the use of a series of locks.

Towards the end of the ice age between 13,000 and 19,000 years ago [3], at least 40 ice dams at Glacial Lake Missoula ruptured, causing the Columbia River drainage basin to experience catastrophic floods [6] [7] (Figure 6). The floodwaters flowed rapidly across eastern Washington and created the channeled scablands, dry falls (Figure 7) greater in size than Niagara Falls, and flowed into the Pacific Ocean (Figure 8). The floodwaters cut and gouged the basalt rock underlying the deep soils. Soils can be found on buttes above the gouged scablands. The water depth varied from $120 \mathrm{~m}$ to $300 \mathrm{~m}$. Sediment was also deposited on the broad, flat bottomlands after the floodwaters slowed.

The Columbia drains $668,000 \mathrm{~km}^{2}$ with $85 \%$ of the basin in the United States [8] and $15 \%$ in Canada. The major tributaries include the Snake, Kootenany, Spokane, Pend Oreille, Okanogan, Cowlitz, Yakima, and Willamette Rivers. Low flows occur in autumn and winter causing water shortages at hydroelectric plants (Figure 9) and restricting navigation. Peak flows occur in the late spring and early summer as a result of snow melt. Native American peoples inhabited the Columbia River basin for centuries. In 1775 Spanish explorers, sailed up the Pacific coast and were apparently the first Europeans to reach the mouth of the Columbia River, but thought it was an estuary. Robert Gray, a Boston trader, sailed up the Columbia River in 1792.

Lewis left Washington D.C. in the spring of 1803 and traveled to Pittsburgh via Philadelphia to get his new boat for the trip down the Ohio River. Later at Clarkville (Indiana Territory) Clark jointed the Expedition. At Cairo, Illinois Lewis and Clark traveled north on the Mississippi River and then turned northwest via the Missouri River. They traveled on horseback over the Rocky Mountains to Clearwater, Snake and the Columbia rivers and finally to the Pacific Ocean. The Lewis and Clark Expedition wintered at the Columbia River mouth in 1805-1806 (Figure 10). David Thompson explored most of the river between 1807 and 1811 for the North West Company. By then, the Americans had already built Fort Astoria by 1811. Other Hudson's Bay Company outposts were established at Fort Walla Walla (1818) and Fort Vancouver (1825).

The primary objectives of the paper are: 1) to document how the geological 


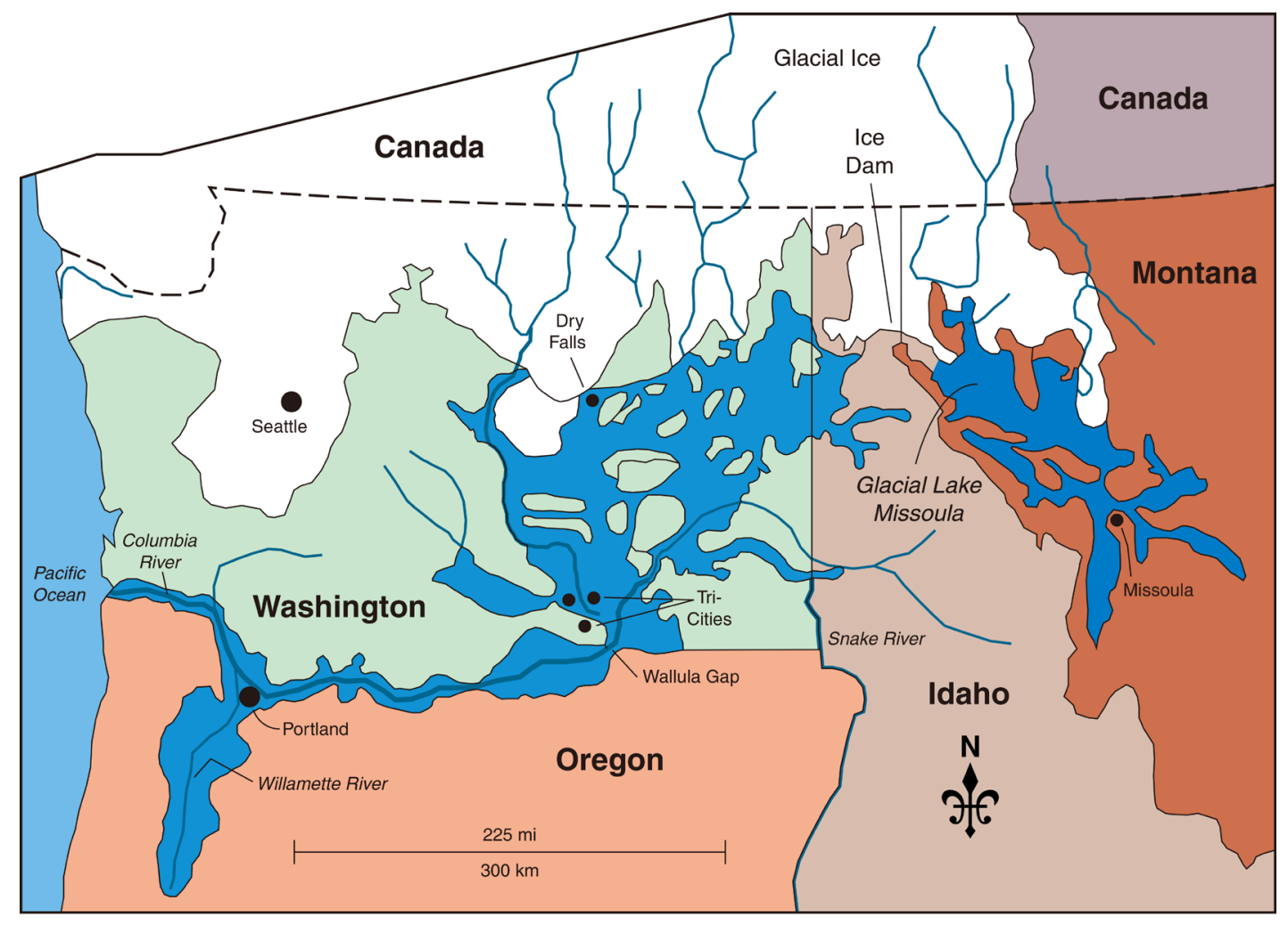

Legend

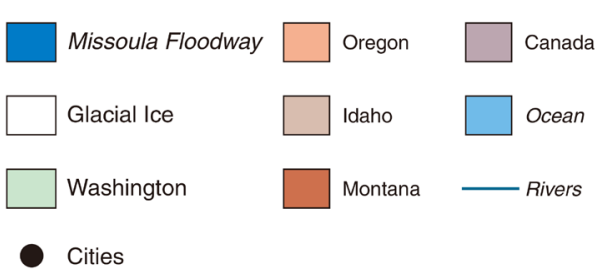

Figure 6. The Glacial Lake Missoula's $600 \mathrm{~km}$ path to the Pacific Ocean. The ice dam blocking Lake Missoula breached many times. Map by Mic Greenberg.

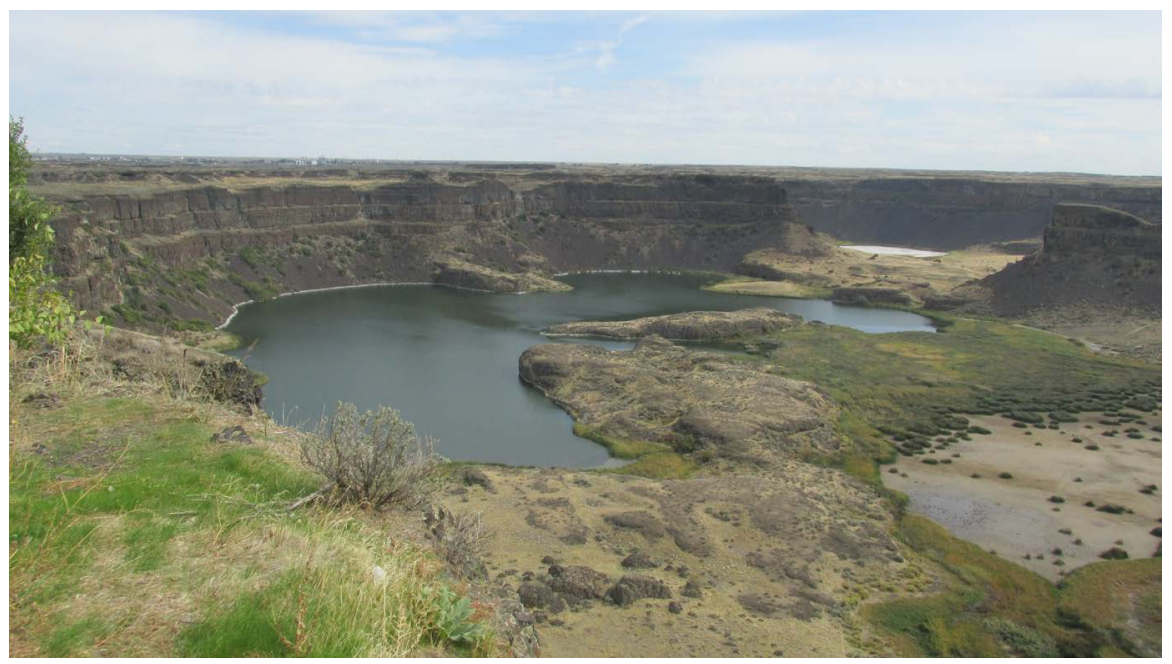

Figure 7. The Lake Missoula floodwaters passed over the dry falls on a tributary of the Columbia River. 


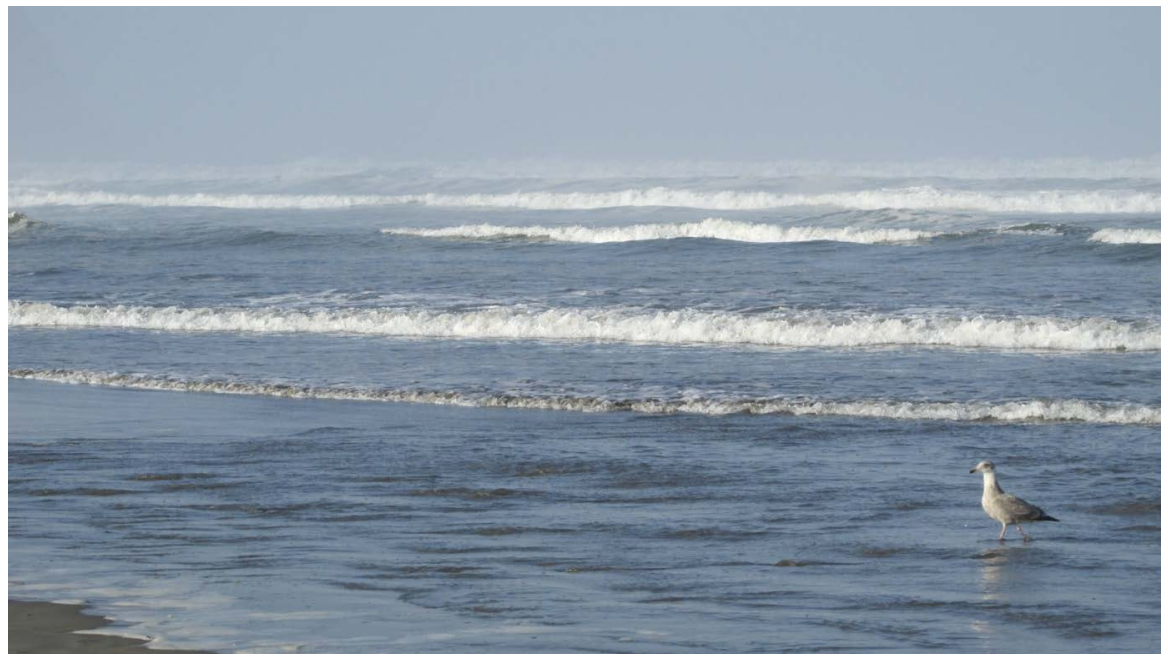

Figure 8. The Pacific Ocean south of the mouth of the Columbia River.

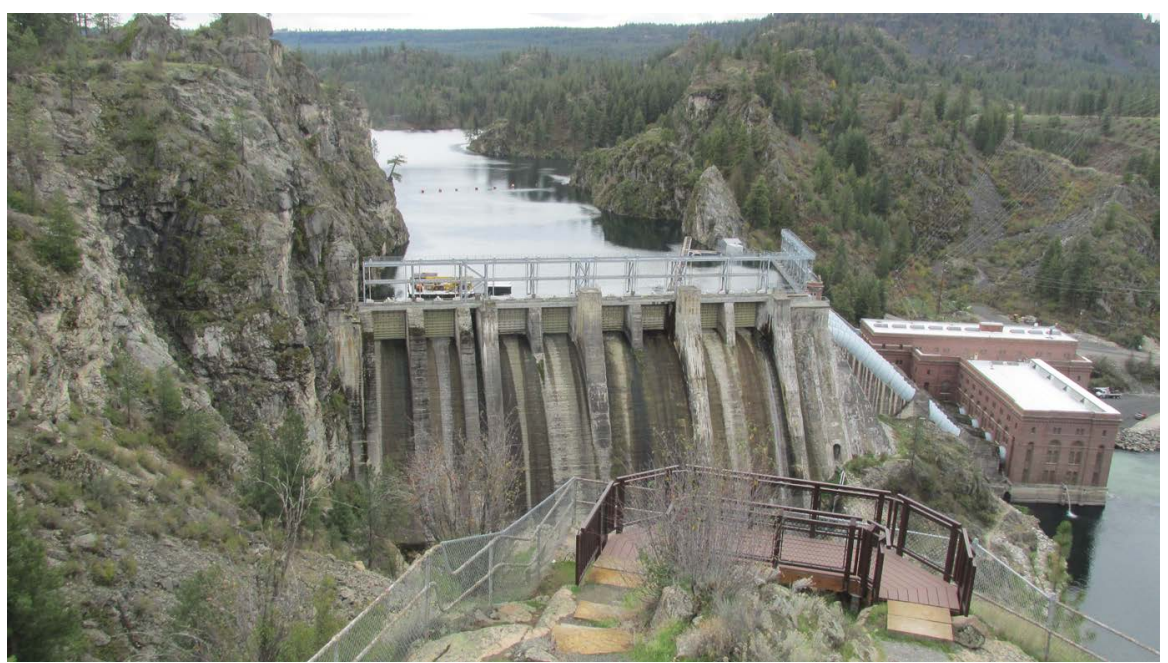

Figure 9. Dam on the Columbia near Spokane, Washington.

and landscape resources of the Columbia River have contributed to the successful economic and water resource development of a historically rich region in North America, 2) to identify the environmental and natural resource risks to the Columbia River basin and 3) to create a generation of people who care about the environmental stewardship and protection of the river and landscape resources.

\section{Site Location}

\subsection{Geology and Soils}

The Pacific Northwest was not originally part of North America. However, as a result of the process of plate tectonics it did become part of the North American continent. The westward drift of the Farallon Plate sub-ducted under the western margin of the continent. It carried island arcs which were accreted to the North American continent and lead to the creation of the Pacific Northwest 


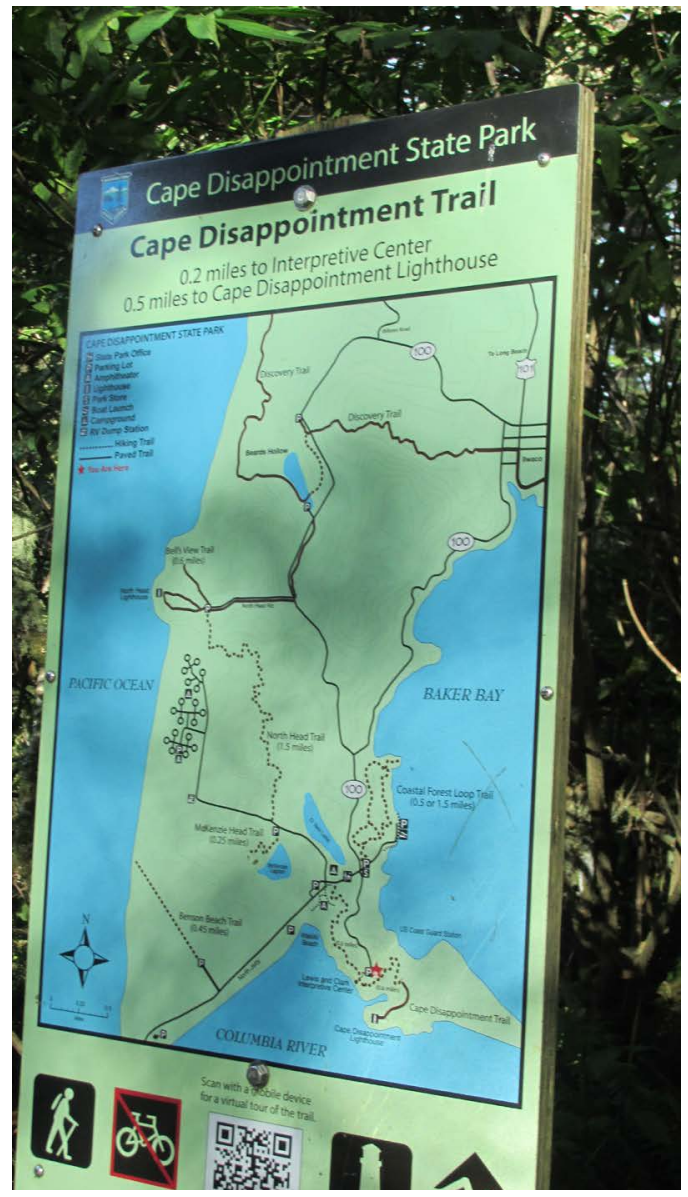

Figure 10. Cape Disappointment near the mouth of the Columbia River east of the Pacific Ocean and was the end of the trail for Lewis and Clark.

between 90 and 150 million years ago [6]. The general outline of the Columbia watershed was completed about 40 to 60 million years ago. However, it lay under a large inland sea which was later subject to uplift. Between 20 and 50 million years ago, the Columbia River landscape was modified by volcanic eruptions. The lower reaches of the ancient river passed through a valley adjacent to Mount Hood. The ancestral Columbia River carried erosional sediments (Figure 11) while erupting volcanoes filled the air with ash (Figure 12). The river built a 3.2 $\mathrm{km}$ thick delta underlying the foothills of the Coast Range. Between 6 and 7 million years ago, huge outpourings of basalt lava covered the Columbia River plateau which re-routed the river to its present course [6].

The modern Cascade Range began to uplift 4 to 5 million years ago. The Columbia River deepened the Columbia River Gorge by cutting through the uplifted mountains. Landslides occurred at several places along the River causing the floodwater to pool into large temporary lakes where sediments were deposited. Water depths have been estimated at $120 \mathrm{~m}$ over modern Portland, Oregon and $300 \mathrm{~m}$ at Wallula Gap. The floods' periodic inundation of the lower Columbia River Plateau deposited rich sediments. The current Willamette Valley farmers of Figure 13 cultivated the soils developed in alluvial and lacustrine sediments from 


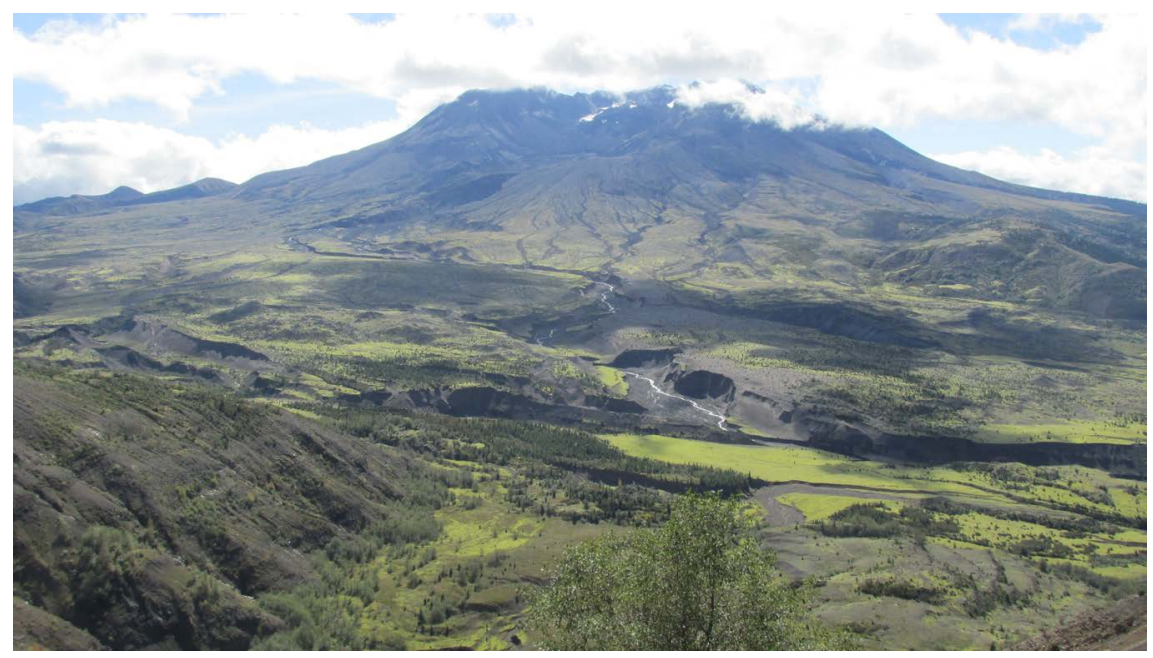

Figure 11. Mount St. Helens after the 1980 eruption and landslide. The mud and lava flowed into the North Fork of Toutle River and on towards the Columbia River.

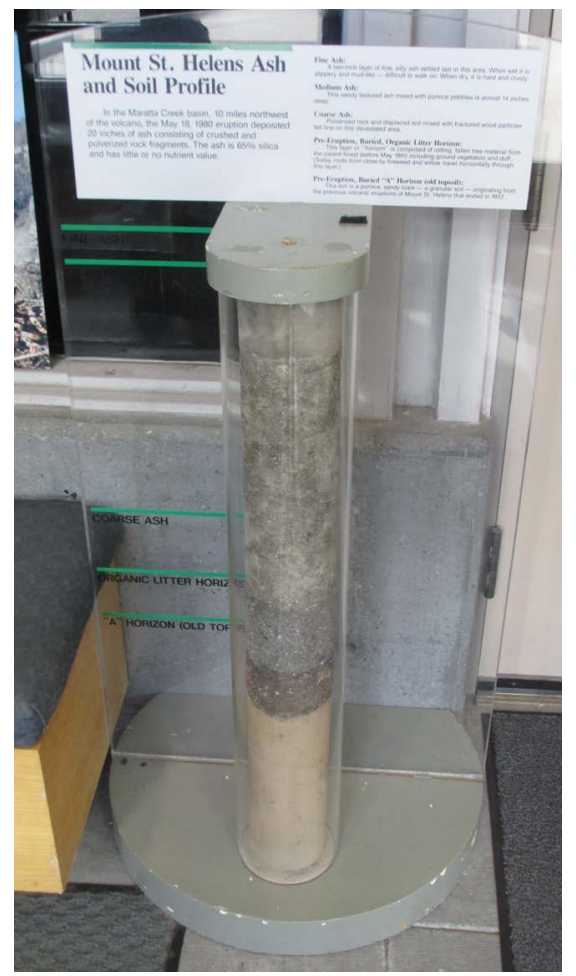

Figure 12. The volcanic ash fell on the nearby soils and buried the existing soil profile. The coarse ash fell first and then the finer ash.

Washington's Palouse and the Columbia River watershed [3].

\subsection{Bonneville Slide}

During the last few thousand years, a series of huge landslides occurred on the north side of the Columbia River Gorge. Massive amounts of debris from Greenleaf Peak and Table Mountain (Figure 14) were deposited (Figure 15) in the gorge near the site of the modern Dalles Dam (Figure 16). The most significant and recent 


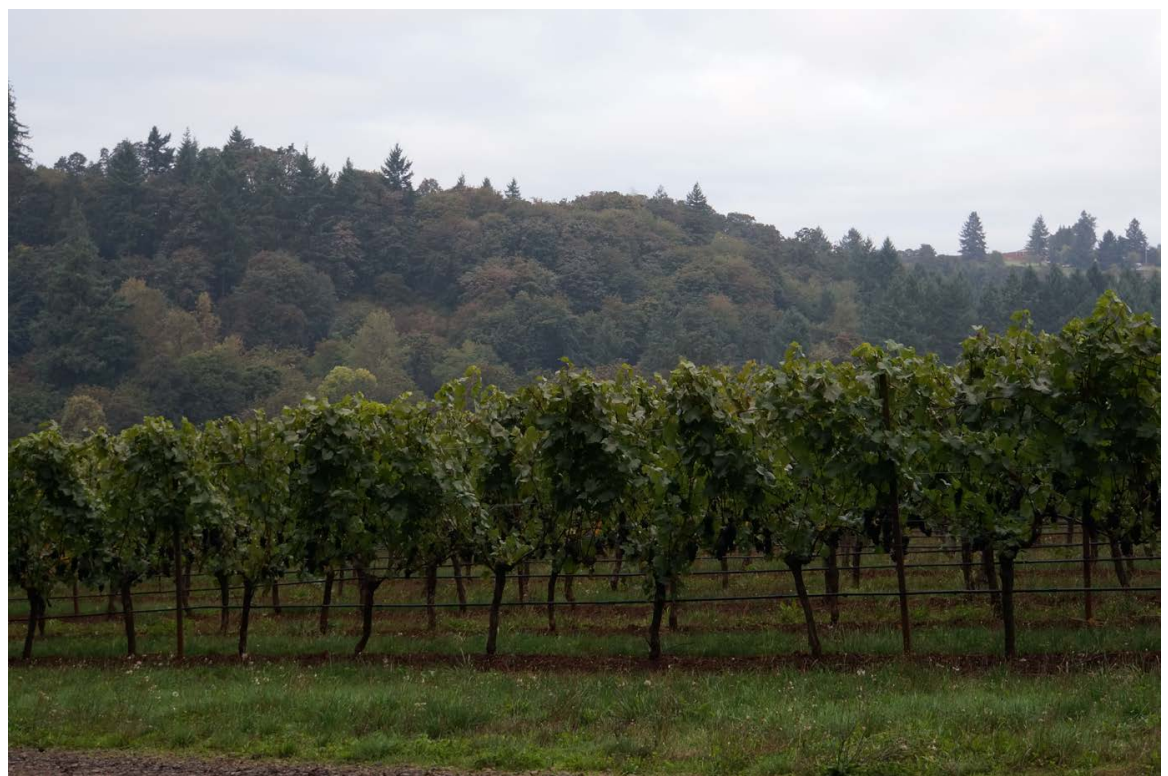

Figure 13. Rolling Willamette Valley landscape. Photograph by Lois Wright Morton.

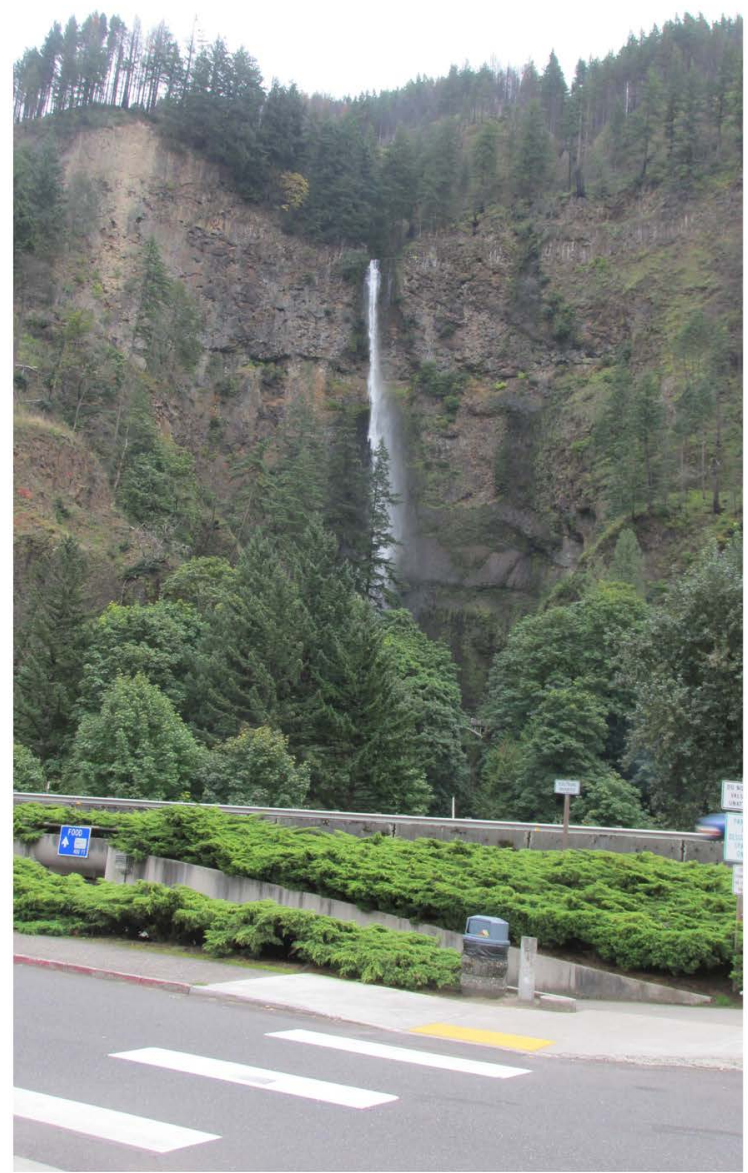

Figure 14. Multnomah Falls at Table Mountain and south of the Columbia River near the narrows. 
landslide, the Bonneville Slide (Figure 15), occurred between 1060 and 1760 C.E. and filled $5.6 \mathrm{~km}$ of the river valley and blocked the Columbia River. The later date links with 1700 C.E. Cascadia earthquake. The Bonneville Slide pile of debris blocked the river until the rising water topped the debris pile and eroded away the finer soil and sediment. The new $2.4 \mathrm{~km}$ channel was created south of the previous channel leaving debris in the valley and creating the Cascade Rapids [9]. Native American oral histories described the formation and destruction of the Bridge of the Gods. The bridge matches the geological records of the Bonneville Slide, and connected the Washington and Oregon sides of the river in the Columbia River Gorge [10]. In 1980, Mount St. Helens (Figure 11) erupted and

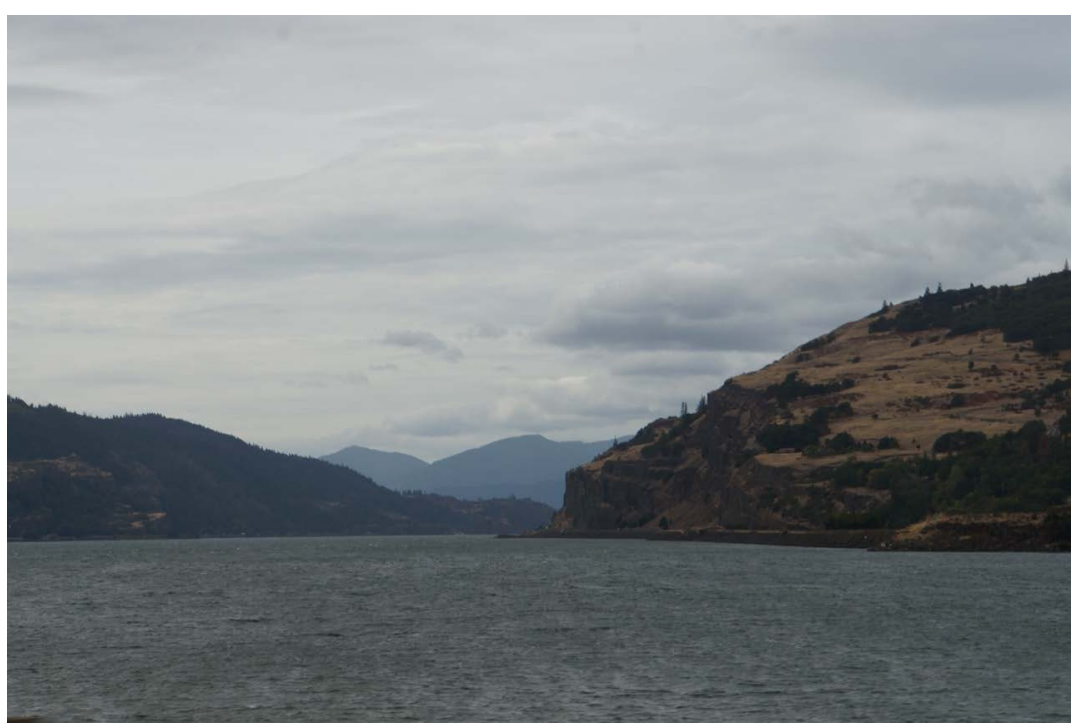

Figure 15. Bonneville slide location and remnants which was carved by the Columbia River during the past 600 years. Native Americans passed on the landslide event story to their offspring.

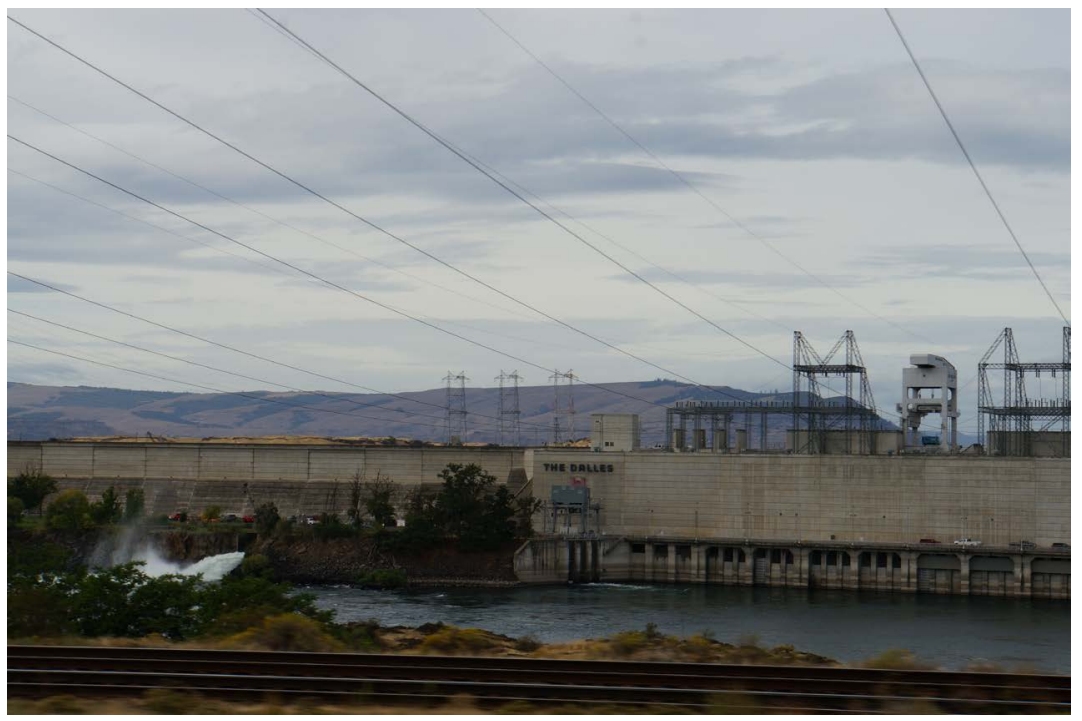

Figure 16. The Dalles dam which flooded many Native American villages including Celilo Falls and prime salmon fishing spots. 
deposited ash (Figure 12) and sediment in the lower Columbia River which reduced the shipping channel depth by $7.9 \mathrm{~m}$.

\subsection{Indigenous Peoples}

Historians believe that Chinese or Japanese vessels blown off course reached the North American Coast long before the Europeans. Archaeologists found human activity evidence in the Columbia watershed near the confluence of the Snake (Figure 1) and Palouse rivers. About 3500 years ago humans transitioned to a more sedentary lifestyle based primarily on availability of salmon.

Native Americans encountered foreigners in the 1700s and 1800s. American and European vessels explored the coastal area around the mouth of the Columbia River in late $18^{\text {th }}$ century and traded with the natives. The contact proved deadly for Native American tribes as a large part of their population was lost after a smallpox epidemic. In 1793 Alexander Mackenzie, the Canadian explorer, crossed the Columbia River valley in British Columbia [9] [10].

From 1805 to 1806, the Lewis and Clark Expedition traveled through the Oregon territory along the Clearwater, Snake and Columbia rivers. They encountered small settlements of Native Americans. The Indigenous groups of the lower and mid-Columbia River valley were not tribal. The social units were smaller than a village and often a family level. The units would shift with the season following the salmon up and down the River and tributaries.

Historically, the Columbia River salmon and steelhead runs averaged 10 to 16 million fish annually. The most productive and significant Native fishing site was located at Celilo Falls. The establishment of salmon canneries by European settlers in 1866 reduced the salmon population dramatically. By 1908, there was widespread concern about the declining fish populations. That year, Oregon passed two laws limiting fishing on the Columbia River and other rivers. The largest run entering the Columbia since 1938 was 3.2 million fish. As river development continued in 1900s, the major Native fishing sites were flooded by dams, starting in 1938 with Cascades Rapids. In 1948, the use of seine nets was banned. Reservoirs, behind the dams, displaced entire communities and covered some of the major Native American fishing sites. Dam construction interrupted the spawning and migration of anadromous fish. When dams prevented the return to the ocean an entire population of salmon and steelhead died. Modern Columbia and Snake River dams now utilize fish ladders to permit fish to travel upstream. Dams created travel time problems for juvenile salmon and steelhead headed downstream to the ocean. The extra time required to reach the ocean can increase fish mortality rate. In 1957, Celilo Falls, the oldest continuously inhabited community in North America, was submerged, and native fishing communities were displaced by construction of the Dalles Dam (Figure 16) [10]. The local tribes received a \$26.8 million settlement for the loss of Celilo Falls.

\subsection{Willamette Valley "The Land of Flowing Milk and Honey"}

The $240 \mathrm{~km}$ Willamette Valley in Oregon was the favored destination of immi- 
grants using the Oregon Trail, and was promoted in the 1820s as the "Land of Flowing Milk and Honey" (Figure 3 and Figure 4). The Willamette Valley has Mediterranean climate with oceanic features; summers are dry, cloudless and hot, while winters are consistently cloudy, cool and rainy. The steel-covered wheels of the oxen-drawn wagon trains cut into exposed batches of bedrock, and are still visible 200 years later (Figure 4).

The Willamette River flows through the entire valley and into the Columbia River north of the current city of Portland. It is surrounded on three sides by the Oregon Coast Range to the west, the Cascade Range to the east and the Calapooya Mountains to the south. The broad flat plain is Oregon's most agriculturally productive area. Much of the Willamette Valley soil fertility is derived from a series of massive ice-age floods (Figure 6) that came from Lake Missoula in Montana. These floods scoured the landscape across eastern Washington and carried sediment and soil down the tributaries to the Columbia River Gorge. Floodwaters backed up by ice jams flooded the valley to a depth of 90 to $120 \mathrm{~m}$, and, if the floodwaters were at that depth today, modern-day Portland, with an elevation of $6.1 \mathrm{~m}$ above sea level, would be under water. The lake gradually drained leaving highly fertile alluvial soils and layered sedimentary soils on the Willamette Valley floor to a height of about 55 to $61 \mathrm{~m}$ above current sea level. The sediments, soils, alluvial and lacustrine parent materials are up to $1 \mathrm{~km}$ thick in the valley.

Since the 1940s grass farmers have burnt fields as part of their product management system. However, after the smoke irritated residents and frequent highway accidents occurred the burning was banned in 2010. During the 1980s, about $1000 \mathrm{~km}^{2}$ were burnt each year with an exception made for steep terrain and certain species.

Today, the Willamette River and tributaries are vital to the economy of Oregon, and the Willamette Valley is home to $70 \%$ of the state's population and its 6 largest cities, including Portland. The gently rolling hills (Figure 13) surrounding the Willamette Valley is "Oregon Wine Country" with more than 500 wineries, over 7700 ha of vineyards, and some of the best wineries and wines in the world (Figure 17). The best location within the valley for vineyards is on the leeward slopes of the Coastal Range and west of the Willamette River. Additional agricultural products of the Valley include vegetables and berries (Figure 18). The valley also produces most of the grass seed, Christmas trees and hazelnuts for North America markets.

\subsection{Climate}

The Columbia River basin's climate is partly continental and partly marine. The Cascade Range shields the basin from most Pacific Ocean air currents. West of the Cascades, the climate is marine influenced, with cool, dry summers and long, rainy winters. West of the Cascades the upland forests are primarily Douglas firs (Pseudotsuga menziesii), hemlocks (Conium maculatin) and western red cedar 


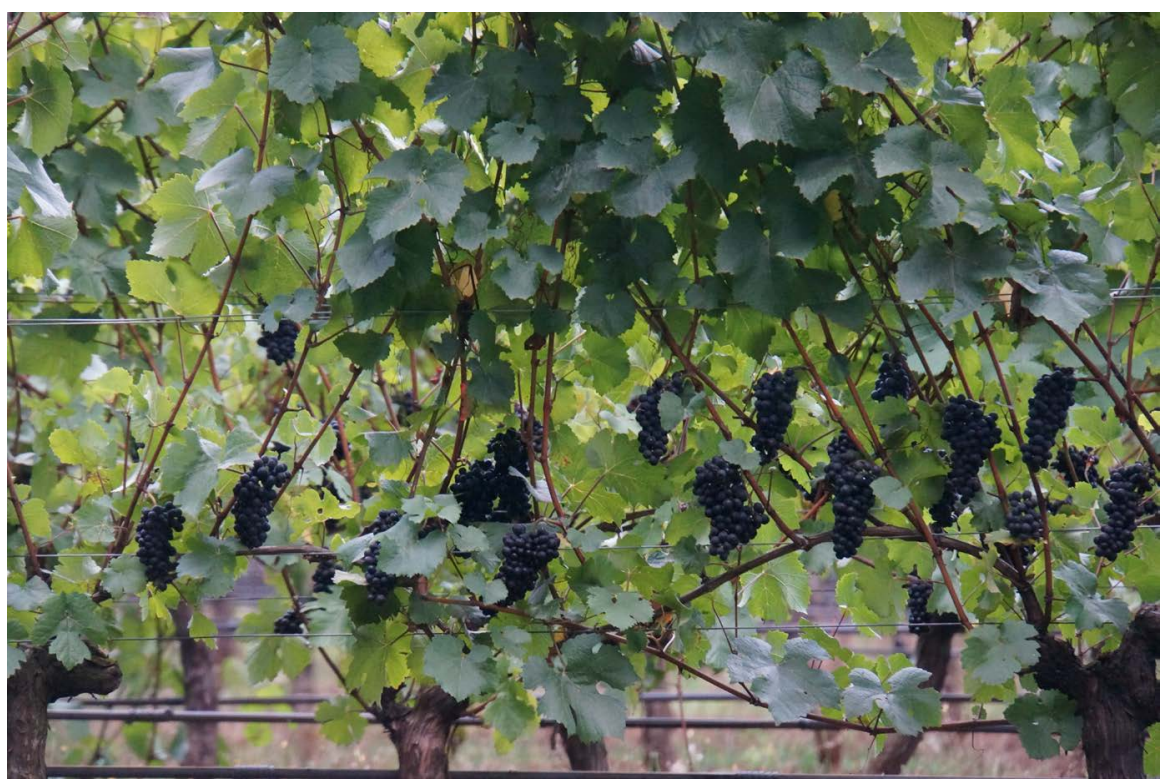

Figure 17. The Willamette land use was changed to urban use such as Portland and the agricultural Land of Flowing Milk and Honey is now covered by vineyards. Photograph by Lois Wright Morton.

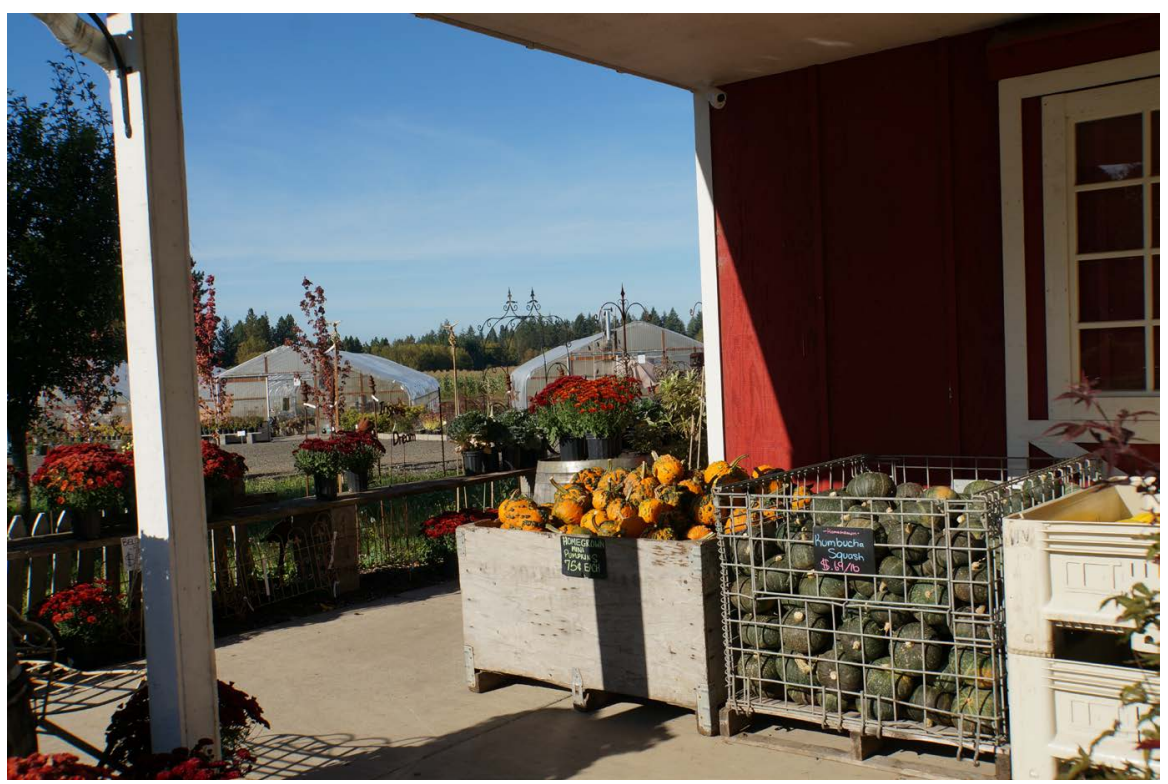

Figure 18. Garden store in the Willamette Valley.

(Thuja plicata). More than half of the original shrub-steppe vegetation was eliminated by draining and farming. Greasewood (Sarcobatus Nees) and alkali salt grass (Distichlis spicata) dominated the poorly drained saline soils. Cheatgrass (Bromus tectorum) has become an invader.

Most of the severe winter storms of the continent interior are blocked out by the Rocky Mountains. The elevation ranges from sea level to $4300 \mathrm{~m}$. High elevations have cold winters and short cool summers. Interior sections are subject to severe droughts and great temperature variability. Annual precipitation varies 
from $2.5 \mathrm{~m}$ in the Cascades to less than $0.2 \mathrm{~m}$ in the interior. Much of the watershed gets less than $30 \mathrm{~cm}$ a year. The Colorado, Columbia, and Missouri watersheds meet at Three Waters Mountain in Wyoming.

\subsection{Plant and Animal Life}

At lower elevations native vegetation are dominated by sagebrush (Artemisia tridentate) and bunchgrasses (Festuca idahoensis). At higher elevations, the dominant vegetation is ponderosa pines (Pinus ponderosa), and, at the highest elevations, vegetation is predominantly firs (Abies), larches (Larix occidentalis) and other pines (Pinus). Willows (Salix) and black cottonwoods (Populus trichocarpa) grow along waterways and on valley sideslopes.

Animal life was varied and abundant prior to European settlement. The Columbia River once had great runs of salmon and steelhead. The basin had large populations of rattle snakes (Crotalus cerastes), beavers (Castor), deer (Cervidae), elk (Cerus canadensis), bears (Ursidae), and bighorn sheep (Ovis canadensis), flocks of waterfowl and upland birds including eagles (Aquila chrysaetos), ospreys (Pandion haliaetus), hawks (Accipitridae) and falcons (Falco falconellus). The ability of the region to sustain large populations of wildlife has been reduced, with particular declines seen in salmon and beavers. There has been much concern over the declining number of salmon. Many fish ladders (Figure 19) and other fish passage facilities on both the Columbia and Snake Rivers are designed to facilitate upstream runs of spawning salmon and steelhead above the dams on the river.

\subsection{Nutrient Cycling}

The natural and anthropogenic processes are involved in the cycling of nutrients in the Columbia River basin. Natural processes include mixing fresh and salt water in an estuary. Climate variability patterns such as the Pacific Decadal Oscillation

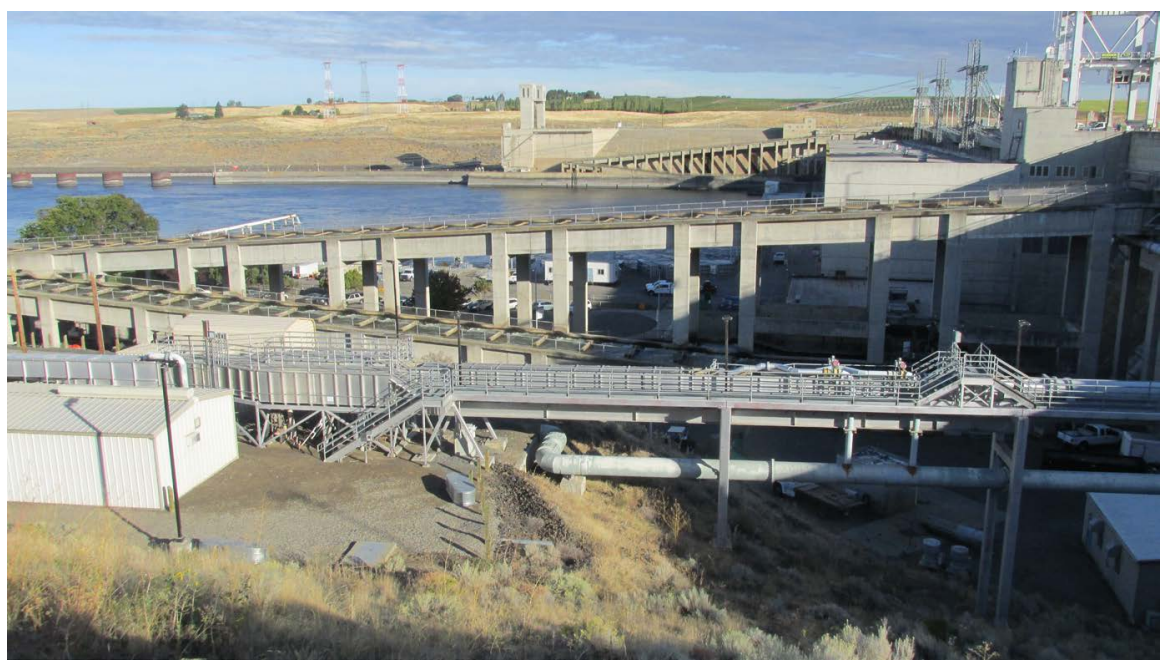

Figure 19. The Ice Harbor dam with a fish ladder on the Snake River just east of the confluence of the Columbia and the Snake Rivers. 
and El Niño Southern Oscillation affect the amount of snow pack and river discharge. The sources of natural nutrients in the Columbia River include leaf litter, weathering, salmon carcasses, runoff from tributaries, and ocean estuary exchange. Major anthropogenic impacts to nutrients in the basin are due to sewage systems, fertilizers from agriculture, logging and construction of dams. In the headwaters, salmon runs are the main source of nutrients. Dams along the river impact nutrient cycling by increasing residence time of nutrients, reducing the transport of silicate to the estuary, which impacts phytoplankton. The dams are also a barrier to salmon migration and can increase the amount of methane produced locally. Ocean upwelling can deliver nitrogen to the estuary and Columbia River discharges high rates of nutrients (Figure 20) into the Pacific Ocean.

\section{Columbia River Watershed}

Most of the $670,000 \mathrm{~km}^{2}$ drainage basin of the Columbia River lies between the Cascade Mountains on the west and the Rocky Mountains on the east. The watershed includes diverse landforms such as arid plateaus, mountains, rolling uplands, river valleys, and deep gorges. The watershed includes the parts of Yellowstone National Park, Grand Teton National Park, Mount Rainier National Park, Glacier National Park, and the North Cascades National Park. Canadian parks include Yohn National Park, Kootenay National Park, Glacier National Park, and Mount Revelstoke National Park. Hells Canyon, the Columbia Gorge, and the deepest gorge in North America, are also in the watershed [11].

\subsection{Mount St. Helens}

Mount St. Helens volcanic eruption on May 18, 1980 was the largest and most destructive in the United States history. By the end of Mount St. Helens cycle of fury and fire, 57 people died. The eruption caused the entire north face to slide

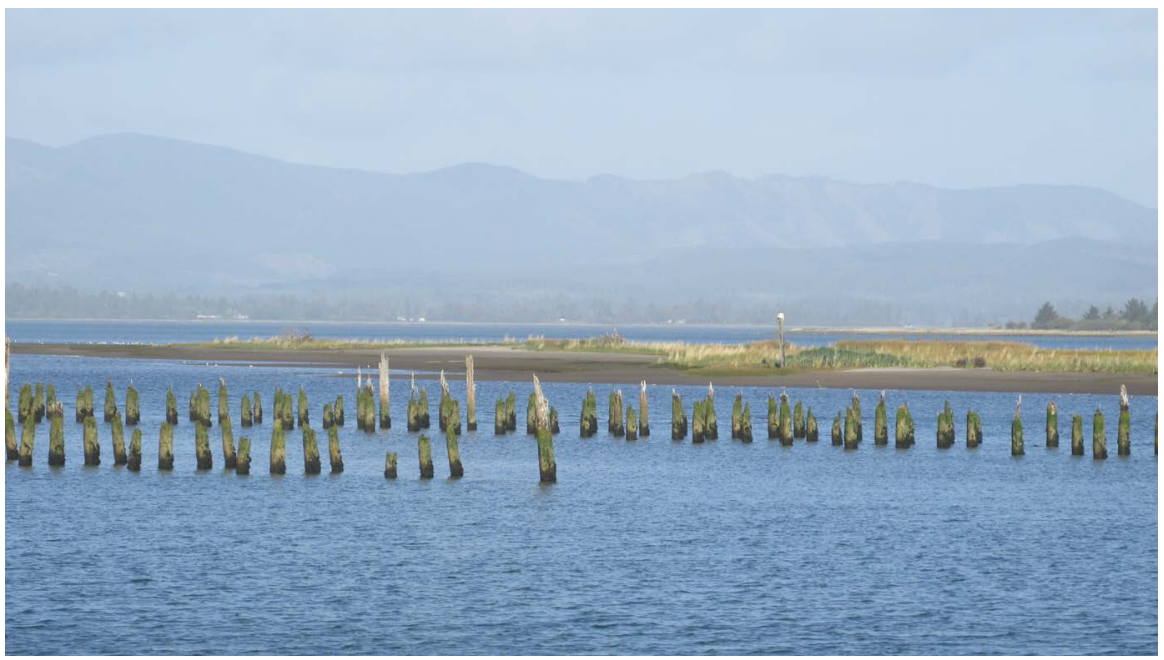

Figure 20. Sand and sediment build up at the mouth of the Columbia River just east of the Pacific Ocean. 
away, creating the largest landslide ever recorded. The partly molten, high-pressure, steam-rich and gas-rich rock in the volcano exploded northwards towards Spirit Lake in a hot mix of lava and pulverized rock. Most of the ash fell 5 to $19 \mathrm{~km}$ from the vent (Figure 6 and Figure 12). The pyroclastic materials were left by the landslide and the resulting deposits formed fan-like patterns of overlapping tongues, sheets, and lobes. The flow deposits created pits on the upper part of the North Fork Toutle River (Figure 11). At the same time, ice, snow and several entire glaciers on the volcano melted, forming a series of volcanic mudslides that reached the Columbia River, nearly $80 \mathrm{~km}$ to the southwest. Because these mudslides adversely affected navigation on the Columbia River, the United States Corps of Engineers were authorized by Congress to build a large sediment control dam on the North Fork of the Toutle River (Figure 21).

\subsection{Population of the Watershed}

In 2016, over 8 million people lived within the Columbia's drainage basin. Of this total, about 1.7 million live in Idaho, 3.5 million in Oregon, 2.1 million in Washington, 0.4 million in Montana and 0.5 million in British Columbia. The population has been rising for many decades and projected to rise to about 10 million by 2030. The highest population densities are found around the Portland (Oregon) and Vancouver (Washington) urban areas.

\subsection{Fish Migration in the Columbia}

In the early 1900s, the challenge of navigating the Columbia was seen as an impediment to the economic development of the Inland Empire region east of the Cascades. The dredging and dam building that followed would disrupt the rivers' natural flow, but provide electricity, irrigation, navigation and other regional benefits. In addition to dams, the establishment of fish canneries in 1867 contributed

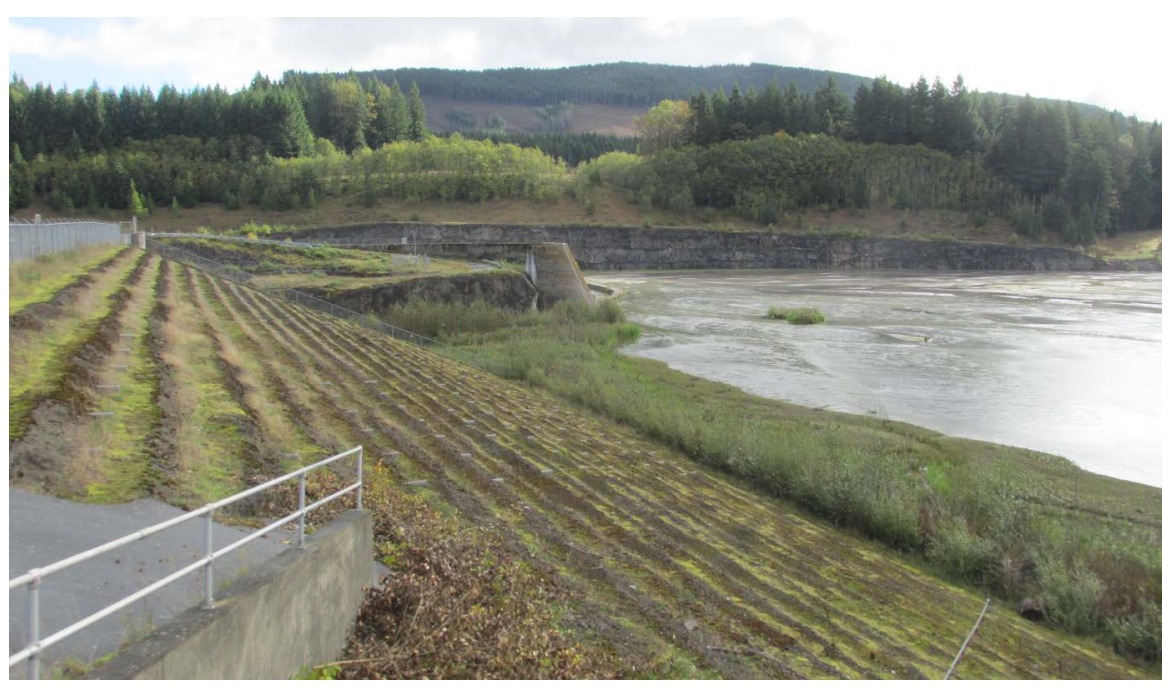

Figure 21. The Mount St. Helens mudflows reached the Columbia River and adversely affected navigation so Congress authorized the United State Corps of Engineers to block the sediments on the North Fork of the Toutle River. 
to dramatic declines in salmon populations.

By 1908, there was widespread concern about the decline of sturgeon and salmon in the Columbia basin. Sockeye, Coho and Chinook salmon and steelhead migrate up rivers at the end of their life cycle to spawn in the streams where they were born. White sturgeon (Acipenser transmontanus) takes 15 to 25 years to mature and migrate between the upstream habitat and the ocean several times during their lives. The migration of anadromous fish moving upstream was interrupted by dams. The extra time required for juvenile salmon to make it downstream to the ocean, due to the presence of dams and the lakes they create, can also increase mortality rates. Some Snake River and Columbia dams utilize ladders (Figure 19) to permit fish to travel upstream. In 1908, Oregon also passed two laws limiting fishing on the Columbia and tributaries. The use of seine nets was banned in 1948. In 1994, US Secretary of Interior Bruce Babbitt first proposed removal of several Pacific Northwest dams due to their impact on salmon spawning. There were 227 Columbia River and tributary dams, many without fish ladders, in the drainage basin but some have been or will be removed.

\subsection{Hydroelectric Power}

One of the world's greatest sources of hydroelectric power is the dams on the Columbia River and tributaries which generate one third of the total hydropower of the United States. In the early 1900s, dams were been built across the river for navigation, irrigation, power generation, and flood control. There are 14 hydroelectric dams in the Columbia main stem including the Grand Coulee Dam (Figure 22 and Figure 23) and many more on the tributaries.

\subsection{Economy}

Exploiting the Columbia River's irrigation and hydroelectric potentials was critical

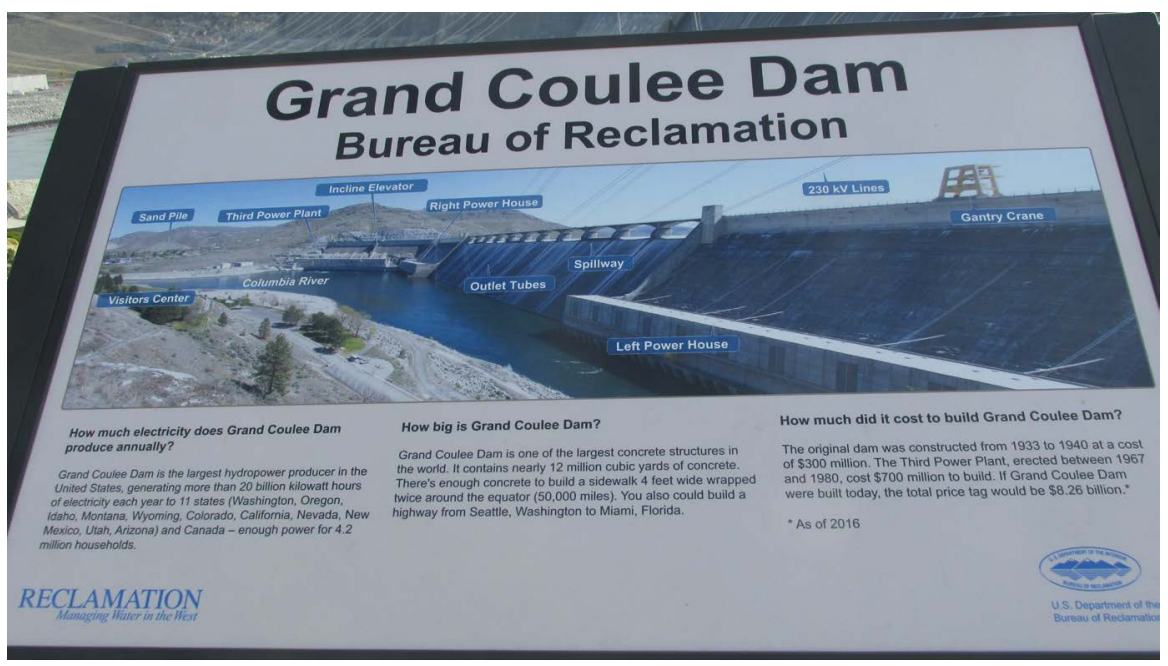

Figure 22. The Grand Coulee dam display. The dam is the largest hydroelectric dam in the world. 


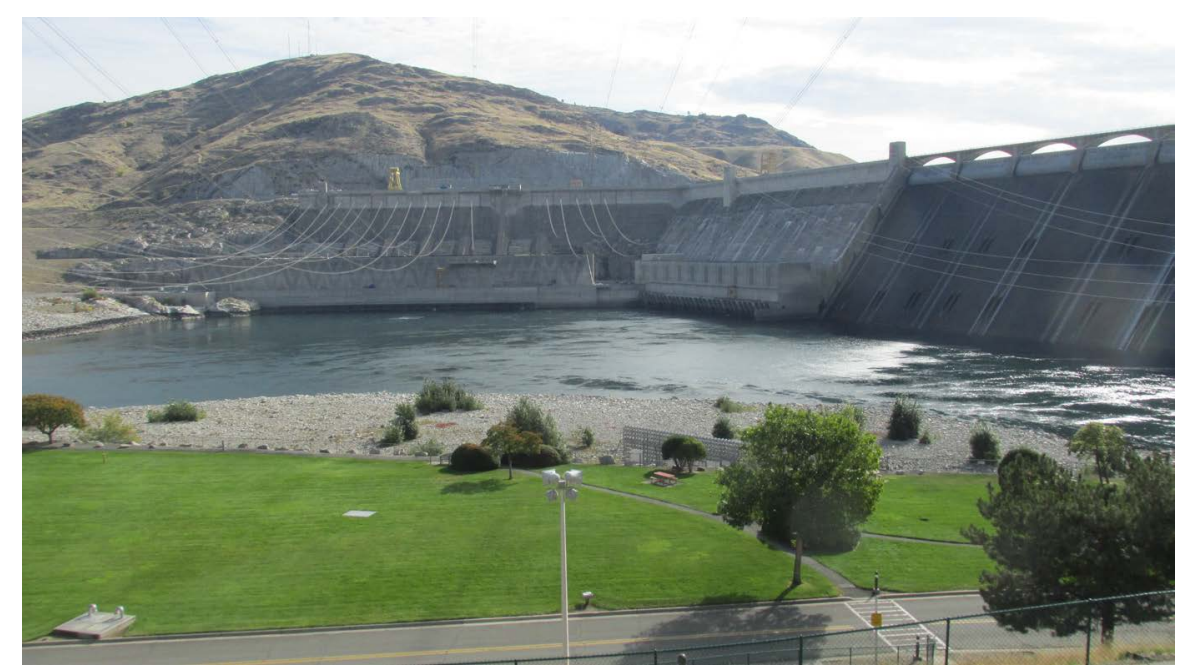

Figure 23. The Grand Coulee dam on the Columbia River. The largest hydroelectric dam in the world.

to developing the region's economy. Many controversies have occurred as the Columbia River was developed economically including the loss of traditional Native American villages, fishing sites and salmon. These were often as a result of divisions of responsibility between public and private agencies. With construction of the Grand Coulee (Figure 23) and Bonneville dams by the federal government in 1930's multipurpose development of the Columbia River Valley was possible. The $390 \mathrm{~m}$ river drop has been converted to a series of "stair steps" by 11 dams on the main river and many dams on the tributaries. In British Columbia there are three upstream storage reservoirs and four on the Lower Columbia River. In the 1970s Grand Coulee Dam, the largest and most complex of the Columbia dams, was completed. The Franklin D. Roosevelt Lake reservoirs reduced winter flows. Water pumped from Franklin D. Roosevelt Lake is used for the first large-scale use of the Columbia River for irrigation. In 1952, irrigation water was used to convert sagebrush and other desert vegetation to agricultural land. The cost of this irrigation project is being paid by profits from the sale of power generated by Grand Coulee Dam. All hydroelectric power plants are connected by high voltage transmission lines that are the backbone of the Pacific Northwest power network. The network sells power to the American Southwest.

\subsection{Nuclear Pollution}

There are 2 nuclear power plants on the Columbia River along the River. Plutonium for nuclear weapons was produced at the Hanford site, which was established as part of the Manhattan Project in 1943. This site, which contains an 80 $\mathrm{km}$ stretch of the Columbia River, is considered the most contaminated nuclear site in the United States. The site had a plutonium production complex with 9 nuclear reactors [12]. The pump system drew water from the Columbia for use in cooling the reactors. The water used in processing was held in large tanks and/or retention basins for up to 6 hours. 
By 1957, the eight plutonium production reactors at Hanford discharged a daily average of 50,000 curies of radioactive material into the Columbia River. The releases were kept secret until a federal government declassification of the documents occurred in late 1980s. At the end of the Cold War the Hanford site nuclear reactors were decommissioned. The site became one of the world's largest environmental cleanup efforts. Nearby aquifers contained an estimated 1 billion $\mathrm{m}^{3}$ of groundwater contaminated by high-levels of nuclear waste that leaked out of storage tanks. As of 2008, approximately $3785 \mathrm{~m}^{3}$ of highly radioactive waste was traveling through the groundwater and will take 10 to 50 years to reach the Columbia River.

\subsection{Other Pollutants}

Other pollutants are found in the river including bacteria, chemical pesticides, dioxins, arsenic and polychlorinated biphenyls (PCB). Water quality is an important factor in survival of plants and wildlife that are found in the Columbia River watershed. A number of clean-up efforts are underway including Superfund projects at Lake Roosevelt, Portland Harbor, and Hanford. Clear cutting timber has increased sediment in runoff water. The 1994 Northwest Forest Plan mandated that timber companies consider environmental impacts on Columbia River and tributaries.

\section{Conclusions}

Overfishing, canneries, exploitation, navigation (Figure 24), water pollution from nuclear reactors, dams without fish ladders, generation of hydroelectricity, irrigation, timber cutting soil erosion and mining have all taken a toll on the Columbia River salmon, sturgeon and steelhead populations. Prior to European

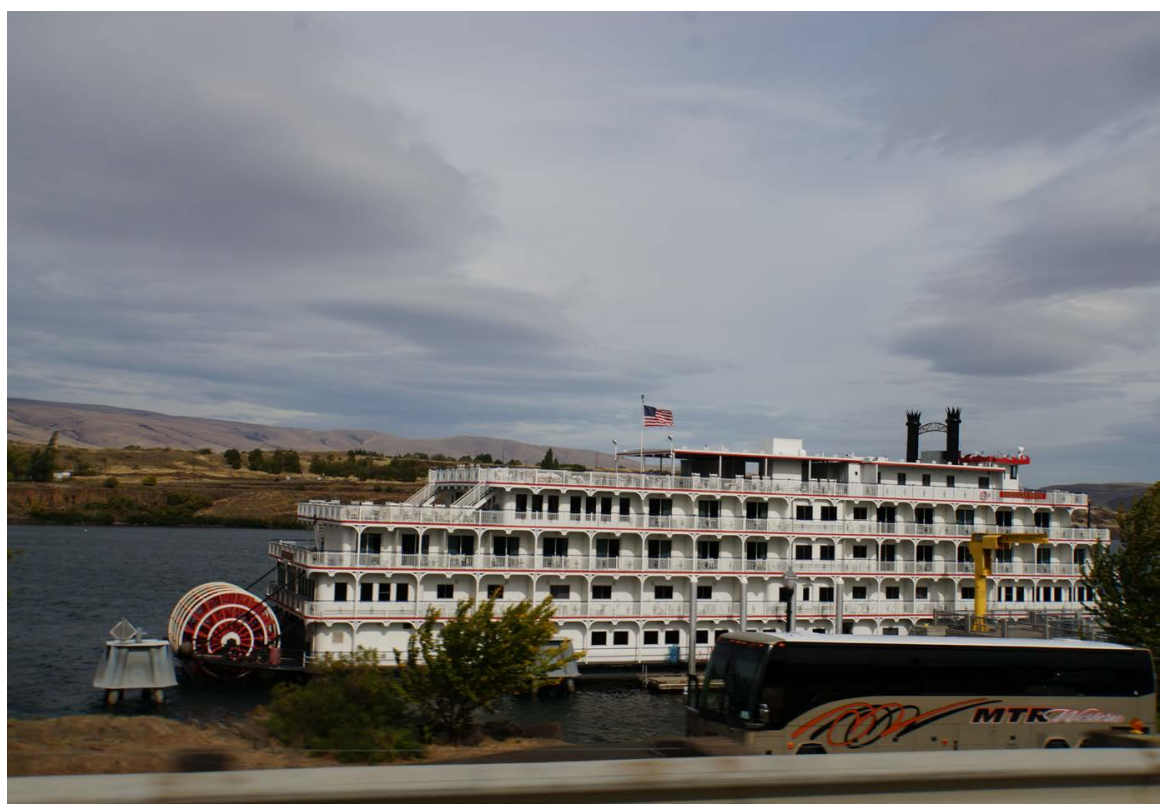

Figure 24. A cruise ship traveling on the Columbia River from Pacific Ocean to Lewiston. 
settlement, the Columbia River salmon and steelhead runs averaged 10 to 16 million fish annually. The fish runs since 1938 have been reduced by 80 percent. Establishment of salmon and steelhead canneries in 1867, coupled with overfishing by European settlers, had reduced fish populations. By 1908, Oregon passed two laws limiting fishing on the Columbia River and tributaries. In 1948, the use of seine nets was banned. Dam construction to aid navigation and for irrigation interrupted the migration and spawning of anadromous fishes. Newer dams utilize fish ladders to permit fish to travel upstream. Dams create time increased mortality rate for juvenile salmon headed downstream to the Pacific Ocean. The removal of dams has accelerated in an effort to mitigate the adverse effects on salmon spawning.

The Columbia basin and the Land of Flowing Milk and Honey was once an idyllic destination for westward-travelling explorers on the Oregon Trail owing to its rich geology, favorable climate and fertile soils. As the region grew, the key to its prosperity was believed to lie in the intelligent development of navigation and energy potential within the Columbia River and tributaries. Unfortunately, this development, coupled with expanding human populations, has led to the decline of salmon and sturgeon populations in the Columbia River basin. New conservation efforts and a change in environmental priorities will hopefully lead to the stewardship, replenishment and protection of natural resources in this unique and important area of the country.

\section{Acknowledgements}

Published with funding support from USDA, NIFA, Water Division and the Department of Natural Resources with the approval of the Director of the Illinois Office of Research, College of Agricultural, Consumer, and Environmental Science, University of Illinois, Urbana, Illinois.

\section{Conflicts of Interest}

The authors declare no conflicts of interest regarding the publication of this paper.

\section{References}

[1] Olson, K.R. and Morton, L.W. (2017) Managing Lower Missouri River for Sediment Reduction, Navigation and Agriculture. Journal of Soil and Water Conservation, 72, 80A-86A. https://doi.org/10.2489/jswc.72.4.80A

[2] Olson, K.R. and Morton, L.W. (2017) Managing Upper Missouri River for Flood Control, Energy, Irrigation and Agriculture. Journal of Soil and Water Conservation, 72, 105A-110A. https://doi.org/10.2489/jswc.72.5.105A

[3] Olson, K.R. and Suski, C.D. (2020) St. Lawrence Seaway: Navigation on Gulf of Saint Lawrence Estuary and the St. Lawrence River. Journal of Water Resource and Protection, 12, 672-691. https://doi.org/10.4236/jwarp.2020.128041

[4] Dietrich, W. (1995) Northwest Passage. The Great Columbia River. University of Washington Press, Seattle. 
[5] Loy, W.G., Allan, S., Buckley, A.R. and Meacham, J.E. (2001) Atlas of Oregon. 2nd Edition. University of Oregon Press, Eugene, Oregon.

[6] Bishop, E.M. (2003) In Search of Ancient Oregon: A Geological and Natural History. Timber Press, Portland, Oregon.

[7] Dohnal, C. (2003) Columbia River Gorge: National Treasure on the Old Oregon Trail. Arcadia Publishing, Charleston, South Carolina.

[8] Benke, A.C and Cushing, C.E. (2005) Rivers of North America. Elsevier, New York.

[9] Meinig, D.W. (1995) The Great Columbia Plain (Weyerhaeuser Environmental Classic. University of Washington Press, Seattle.

[10] Boyd, R. (1996) People of the Dalles: The Indians of Wascopam Mission. University of Nebraska Press, Lincoln.

[11] Allen, J.E., Burns, M. and Sargent, S.C. (1986) Cataclysms of the Columbia: A Layman'S Guide to the Features Produced by the Catastrophic Bret Floods in the Pacific Northwest. Timber Press, Portland, Oregon.

[12] Hanford Health Information Network (2000) An Overview of Hanford and Radiation Health Effects.

https://www.doh.wa.gov/Portals/1/Documents/Pubs/320-029 2000ar e.pdf 